Article

\title{
Krishnolides A-D: New 2-Ketokhayanolides from the Krishna Mangrove, Xylocarpus moluccensis
}

\author{
Qun Zhang ${ }^{1}$, Tirumani Satyanandamurty ${ }^{2}$, Li Shen ${ }^{1, *}$ (i) and Jun $\mathrm{Wu}^{3, *}$ \\ 1 Marine Drugs Research Center, College of Pharmacy, Jinan University, 601 Huangpu Avenue West, \\ Guangzhou 510632, China; zhangqun0917@163.com \\ 2 Government Degree College at Amadala Valasa, Srikakulam District, Andhra Pradesh 532185, India; \\ satyananda_murty@yahoo.com \\ 3 School of Pharmaceutical Sciences, Southern Medical University, 1838 Guangzhou Avenue North, \\ Guangzhou 510515, China \\ * Correspondence: shenli6052@sina.com or shenli6052@jnu.edu.cn (L.S.); wwujun2003@yahoo.com (J.W.); \\ Tel.: +86-20-8522-2050 (L.S.)
}

Received: 11 September 2017; Accepted: 19 October 2017; Published: 27 October 2017

\begin{abstract}
Four new khayanolide-type limonoids with a 2-carbonyl group, named krishnolides A-D (1-4), were isolated from the seeds of an Indian mangrove, Xylocarpus moluccensis, collected in the mangrove swamp of Krishna estuary, Andhra Pradesh. The relative and absolute configurations of these compounds were established by HR-ESIMS, extensive NMR investigations, single-crystal X-ray diffraction analysis with $\mathrm{CuK} \alpha$ radiation, and experimental electronic circular dichroism (ECD) spectra. Krishnolides A-D are unusual khayanolides containing two large ester substituents of five or four carbon atoms at the C-3 and C-30 positions, respectively. Krishnolide A, containing an 8,14-epoxy group, exhibited moderate anti-Human Immunodeficiency Virus (HIV) activity with an IC $_{50}$ value of $17.45 \pm 1.65 \mu \mathrm{M}$ and a $\mathrm{CC}_{50}$ value of $78.45 \pm 1.69 \mu \mathrm{M}$, respectively. This is not only the first report of natural khayanolides from Indian mangroves of the genus Xylocarpus, but also the first report of the anti-HIV activity of khayanolide.
\end{abstract}

Keywords: mangrove; Xylocarpus moluccensis; limonoid; khayanolide; anti-HIV

\section{Introduction}

Plants of the genus Xylocarpus, belonging to the family Meliaceae, are mangroves mainly found in East Africa, India, Bangladesh, Southeast Asia, Southern China, and Northern Australia. Limonoids are the main secondary metabolites of these mangroves [1-3]. Previously, a variety of limonoids with abundant structural diversity and various bioactivities, such as antiviral and antitumor activities, were identified from seeds of the mangrove X. moluccensis [4-7]. Thaixylomolin I, a khayanolide-type limonoid obtained from the Thai X. moluccensis, exhibited stronger inhibitory activity against pandemic influenza A virus (subtype H1N1) than that of the antiviral drug, ribavirin [6]. Khayanolides are a small group of limonoids containing an octahydro- $1 \mathrm{H}-1,6$-methanoindene moiety as the ring A/B-fused carbotricyclic core. To date, only 36 khayanolides have been reported [8-21]. In order to search for new antiviral limonoids, seeds of the Indian X. moluccensis, collected in the mangrove swamp of Krishna estuary, Andhra Pradesh, were further investigated to afford four new khayanolides, named krishnolides A-D (1-4) (Figure 1). Herein, we report the isolation, structural elucidation, and anti-HIV activities of these khayanolides. 

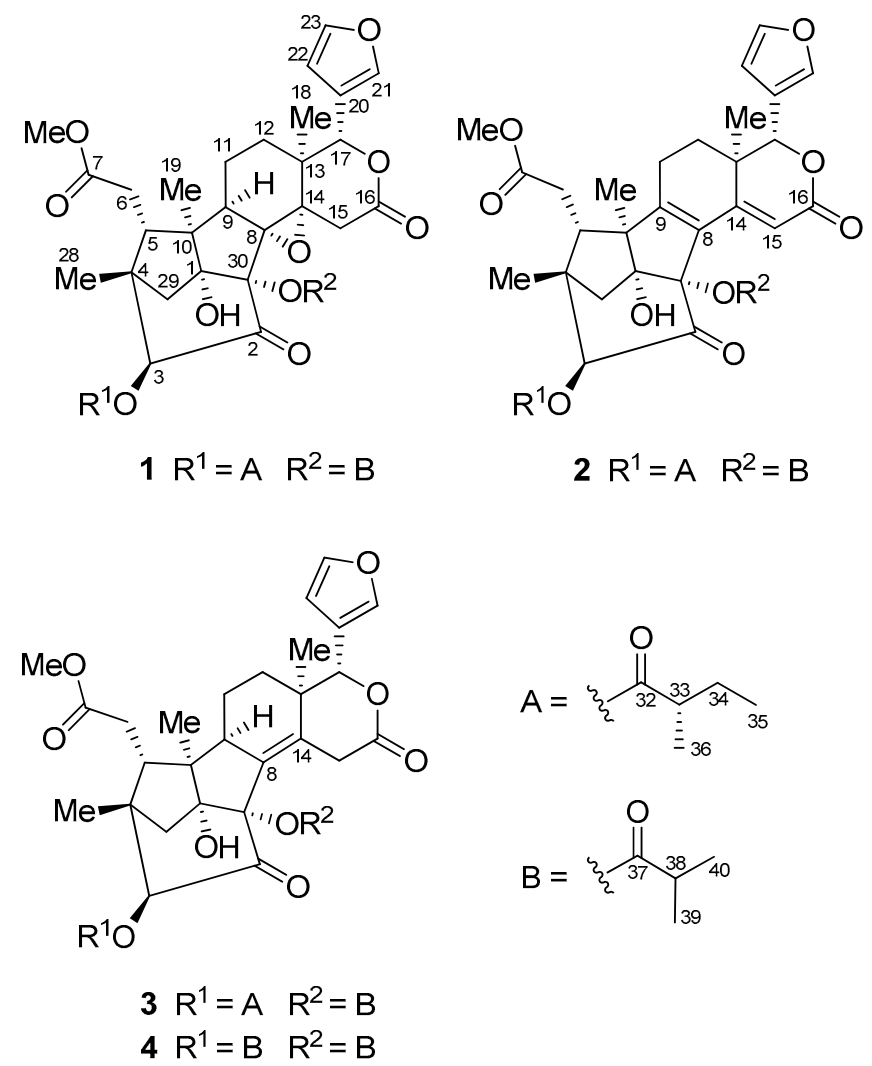

Figure 1. Structures of compounds 1-4.

\section{Results and Discussion}

Compound 1 was obtained as a colorless crystal. Its molecular formula was established as $\mathrm{C}_{36} \mathrm{H}_{46} \mathrm{O}_{12}$ by the positive HR-ESIMS ion peak at $m / z 693.2871$ (calcd. for $[\mathrm{M}+\mathrm{Na}]^{+} 671.2881$ ), indicating 14 degrees of unsaturation. According to the ${ }^{1} \mathrm{H}$ and ${ }^{13} \mathrm{C}$ NMR spectroscopic data of 1 (Tables 1 and 2), seven degrees of unsaturation were due to a keto carbonyl group, two carbon-carbon double bonds, and four ester functionalities; thus, the molecule was heptacyclic. The NMR spectroscopic data of 1 resembled those of thaixylomolin K [6], except for the presence of an 8,14-epoxy group $\left(\delta_{\mathrm{C}} 73.6(\mathrm{C}-8), 65.1(\mathrm{C}-14)\right)$, a 3-(2-methyl)butyryloxy function $\left(\delta_{\mathrm{H}} 2.35(\mathrm{~m}), 1.46(\mathrm{~m}), 1.55(\mathrm{~m})\right.$, $\left.0.80(\mathrm{t}, J=7.2 \mathrm{~Hz}), 1.04(\mathrm{~d}, J=7.2 \mathrm{~Hz}) ; \delta_{\mathrm{C}} 175.2(\mathrm{qC}), 40.8(\mathrm{CH}), 26.7\left(\mathrm{CH}_{2}\right), 11.6\left(\mathrm{CH}_{3}\right), 16.3\left(\mathrm{CH}_{3}\right)\right)$, and a 30-isobutyryloxy moiety $\left(\delta_{\mathrm{H}} 2.63(\mathrm{~m}), 1.09(\mathrm{~d}, J=7.2 \mathrm{~Hz}), 1.10(\mathrm{~d}, J=7.2 \mathrm{~Hz}) ; \delta_{\mathrm{C}} 175.6(\mathrm{qC})\right.$, $33.2\left(\mathrm{CH}_{3}\right), 19.0\left(\mathrm{CH}_{3}\right), 18.7(\mathrm{CH})$ ) (Tables 1 and 2, recorded in DMSO- $\left.d_{6}\right)$, and the absence of the $\Delta^{8,14}$ double bond, the 3-acetoxy group, and the C-30 methine moiety. HMBC cross-peaks between H-9/C-8, H-9/C-14, $\mathrm{H}_{2}-15 / \mathrm{C}-8, \mathrm{H}_{2}-15 / \mathrm{C}-14$, and $\mathrm{H}_{3}-18 / \mathrm{C}-14$ confirmed the existence of the 8,14-epoxy group, being corroborated by the degrees of unsaturation of 1 . Those from H-3 ( $\delta 5.44(\mathrm{~s})$ ) to the carbonyl carbon $\left(\delta_{C} 175.2\right.$ (C-32)) of the 2-methylbutyryloxy function placed it at C-3, whereas the location of an isobutyroxy moiety at C-30 was supported by the deshielded quaternary C-30 signal $(\delta 87.2)$ in 1 , as compared to that $(\delta 63.1)$ in thaixylomolin $\mathrm{K}$. HMBC correlations from 1-OH $(\delta 5.86$ (br s)) and $\mathrm{H}_{2}-29(\delta 2.43(1 \mathrm{H}, \mathrm{d}, J=12.6 \mathrm{~Hz}), 2.09(1 \mathrm{H}, \mathrm{d}, J=12.6 \mathrm{~Hz}))$ to $\mathrm{C}-30$ (Figure 2a) demonstrated the above deduction.

The relative configuration of $\mathbf{1}$ was assigned by analysis of the Nuclear Overhauser Effect (NOE) interactions (Figure 2b), of which those between $\mathrm{H}-17 / \mathrm{H}-11 \beta, \mathrm{H}-11 \beta / \mathrm{H}-5, \mathrm{H}-17 / \mathrm{H}-5$, and H-5/H $3-28$ revealed their cofacial relationship and were arbitrarily assigned as the $\beta$-oriented $\mathrm{H}-5, \mathrm{H}-17$, and $\mathrm{H}_{3}$-28. In turn, those between $\mathrm{H}_{3}-18 / \mathrm{H}-15 \alpha, \mathrm{H}_{3}-19 / \mathrm{H}-9, \mathrm{H}_{3}-19 / 1-\mathrm{OH}$, and $\mathrm{H}-9 / 1-\mathrm{OH}$ assigned the $\alpha$-orientation for $\mathrm{H}_{3}-18, \mathrm{H}_{3}-19, \mathrm{H}-9$, and 1-OH. The significant NOE interaction from $\mathrm{H}-3$ to $\mathrm{H}_{\text {pro- } R}-29(\delta 2.43(\mathrm{~d}, J=12.6 \mathrm{~Hz}))$, but not from $\mathrm{H}-3$ to $\mathrm{H}-5$, established $3 \alpha-\mathrm{H}$ and the corresponding 
$3 \beta$-(2-methyl)butyryloxy function. However, the orientation of the 8,14-epoxy group could not be determined by NOE interactions.

Table 1. ${ }^{1} \mathrm{H}$ (400 MHz) NMR spectroscopic data of compounds 1-4 ( $\delta$ in ppm, $J$ in Hz).

\begin{tabular}{|c|c|c|c|c|c|}
\hline Position & $1^{a}$ & $1^{b}$ & $2^{a}$ & $3^{a}$ & $4^{a}$ \\
\hline 3 & $5.68 \mathrm{~s}$ & $5.44 \mathrm{~s}$ & $5.51 \mathrm{~s}$ & $5.22 \mathrm{~s}$ & $5.21 \mathrm{~s}$ \\
\hline 5 & $2.37 \mathrm{~m}$ & 2.16 br d (8.0) & $2.63 \mathrm{~m}$ & $2.49^{\mathrm{c}}$ & $2.48^{\mathrm{c}}$ \\
\hline $6 a$ & 2.22 br d (14.0) & $2.36^{\mathrm{c}}$ & $2.41^{\mathrm{c}}$ & 2.30 br d (12.8) & 2.32 br d (12.8) \\
\hline $6 \mathrm{~b}$ & 2.43 br d (14.0) & $2.42 \mathrm{~m}$ & $2.41^{\mathrm{c}}$ & $2.47^{\mathrm{c}}$ & $2.48^{\mathrm{c}}$ \\
\hline 9 & $2.07 \mathrm{~m}$ & $1.97 \mathrm{~m}$ & & $2.58 \mathrm{~m}$ & $2.59 \mathrm{~m}$ \\
\hline $11 \alpha$ & $1.36^{\mathrm{c}}$ & $1.41^{\mathrm{c}}$ & $2.20 \mathrm{~m}$ & $1.77 \mathrm{~m}$ & $1.78 \mathrm{~m}$ \\
\hline $11 \beta$ & $1.36^{\mathrm{c}}$ & $1.19 \mathrm{~m}$ & $2.50 \mathrm{~m}$ & $1.50^{\mathrm{c}}$ & $1.50^{\mathrm{c}}$ \\
\hline $12 \alpha$ & $1.28 \mathrm{~m}$ & $1.13 \mathrm{~m}$ & $1.59 \mathrm{~m}$ & $1.44 \mathrm{~m}$ & $1.44 \mathrm{~m}$ \\
\hline $12 \beta$ & $1.34^{\mathrm{c}}$ & $1.17^{\mathrm{c}}$ & $1.45 \mathrm{~m}$ & $1.49 \mathrm{~m}$ & $1.50^{\mathrm{c}}$ \\
\hline $15 \alpha$ & $3.06 \mathrm{~d}(19.0)$ & $3.15 \mathrm{~d}(19.0)$ & 6.45 br s & $3.62 \mathrm{dd}(20.0,3.8)$ & $3.62 \mathrm{dd}(20.0,3.8)$ \\
\hline $15 \beta$ & $3.28 \mathrm{~d}(19.0)$ & $3.00 \mathrm{~d}(19.0)$ & & $3.73 \mathrm{dd}(20.0,3.2)$ & $3.74 \mathrm{dd}(20.0,3.2)$ \\
\hline 17 & $5.25 \mathrm{~s}$ & $5.06 \mathrm{~s}$ & $5.08 \mathrm{~s}$ & $5.10 \mathrm{~s}$ & $5.13 \mathrm{~s}$ \\
\hline 18 & $1.13 \mathrm{~s}$ & $1.02 \mathrm{~s}$ & $1.05 \mathrm{~s}$ & $1.05 \mathrm{~s}$ & $1.05 \mathrm{~s}$ \\
\hline 19 & $1.08 \mathrm{~s}$ & $0.98 \mathrm{~s}$ & $1.04 \mathrm{~s}$ & $1.07 \mathrm{~s}$ & $1.07 \mathrm{~s}$ \\
\hline 21 & 7.59 br s & 7.69 br s & 7.47 br s & 7.48 br s & 7.47 br s \\
\hline 22 & 6.45 br s & 6.52 br s & 6.45 br s & $6.43 \mathrm{br} \mathrm{s}$ & 6.42 br s \\
\hline 23 & 7.43 br s & 7.75 br s & 7.43 br s & 7.43 br s & 7.42 br s \\
\hline 28 & $1.05 \mathrm{~s}$ & $0.97 \mathrm{~s}$ & $1.04 \mathrm{~s}$ & $0.98 \mathrm{~s}$ & $0.98 \mathrm{~s}$ \\
\hline $29_{\text {pro-S }}$ & $2.13 \mathrm{~d}(12.6)$ & $2.09 \mathrm{~d}(12.6)$ & $1.97 \mathrm{~d}(12.6)$ & $2.03 \mathrm{~d}(12.8)$ & $2.03 \mathrm{~d}(12.8)$ \\
\hline 29 pro-R & $2.62 \mathrm{~d}(12.6)$ & $2.43 \mathrm{~d}(12.6)$ & $2.65 \mathrm{~d}(12.6)$ & $2.50 \mathrm{~d}(12.8)$ & $2.50 \mathrm{~d}(12.8)$ \\
\hline 7-OMe-31 & $3.70 \mathrm{~s}$ & $3.63 \mathrm{~s}$ & $3.70 \mathrm{~s}$ & $3.66 \mathrm{~s}$ & $3.66 \mathrm{~s}$ \\
\hline \multicolumn{6}{|l|}{ 3-OAcyl } \\
\hline 33 & $2.43, \mathrm{~m}$ & $2.35^{\mathrm{c}}$ & $2.53 \mathrm{~m}$ & $2.49^{\mathrm{c}}$ & $2.65 \mathrm{~m}$ \\
\hline \multirow[t]{2}{*}{34} & $1.52 \mathrm{~m}$ & $1.46 \mathrm{~m}$ & $1.51 \mathrm{~m}$ & $1.51^{\mathrm{c}}$ & $1.19 \mathrm{~d}(7.2)$ \\
\hline & $1.70 \mathrm{~m}$ & $1.55 \mathrm{~m}$ & $1.73 \mathrm{~m}$ & $1.68 \mathrm{~m}$ & \\
\hline 35 & $0.93 \mathrm{t}(7.2)$ & $0.80 \mathrm{t}(7.2)$ & $0.95 \mathrm{t}(7.2)$ & $0.91 \mathrm{t}(7.2)$ & $1.20 \mathrm{~d}(7.2)$ \\
\hline 36 & $1.15 \mathrm{~d}(7.2)$ & $1.04 \mathrm{~d}(7.2)$ & $1.23 \mathrm{~d}(7.2)$ & $1.15 \mathrm{~d}(7.2)$ & \\
\hline \multicolumn{6}{|l|}{ 30-OAcyl } \\
\hline 38 & $2.66 \mathrm{~m}$ & $2.63 \mathrm{~m}$ & $2.66 \mathrm{~m}$ & $2.71 \mathrm{~m}$ & $2.72 \mathrm{~m}$ \\
\hline 39 & $1.21 \mathrm{~d}(7.0)$ & $1.09 \mathrm{~d}(7.2)$ & $1.20 \mathrm{~d}(7.0)$ & $1.20 \mathrm{~d}(7.0)$ & $1.20 \mathrm{~d}(7.0)$ \\
\hline 40 & $1.21 \mathrm{~d}(7.0)$ & $1.10 \mathrm{~d}(7.2)$ & $1.20 \mathrm{~d}(7.0)$ & $1.26 \mathrm{~d}(7.0)$ & $1.26 \mathrm{~d}(7.0)$ \\
\hline $1-\mathrm{OH}$ & & $5.86 \mathrm{~s}$ & & & \\
\hline
\end{tabular}

${ }^{a}$ Recorded in $\mathrm{CDCl}_{3} ;{ }^{\mathrm{b}}$ Recorded in DMSO- $d_{6} ;{ }^{\mathrm{c}}$ Overlapped signals assigned by ${ }^{1} \mathrm{H}-{ }^{1} \mathrm{H}$ COSY, HSQC, and HMBC spectra without designating multiplicity.

Table 2. ${ }^{13} \mathrm{C}(100 \mathrm{MHz})$ NMR spectroscopic data of compounds 1-4 ( $\delta$ in ppm).

\begin{tabular}{|c|c|c|c|c|c|}
\hline Position & $1^{a}$ & $1^{b}$ & $2^{a}$ & $3^{a}$ & $4^{a}$ \\
\hline 1 & $85.5 \mathrm{qC}$ & $85.0 \mathrm{qC}$ & $88.6 \mathrm{qC}$ & $86.2 \mathrm{qC}$ & $86.2 \mathrm{qC}$ \\
\hline 2 & $203.2 \mathrm{qC}$ & $205.9 \mathrm{qC}$ & $197.9 \mathrm{qC}$ & $199.2 \mathrm{qC}$ & $199.4 \mathrm{qC}$ \\
\hline 3 & $83.1 \mathrm{CH}$ & $83.4 \mathrm{CH}$ & $79.1 \mathrm{CH}$ & $79.9 \mathrm{CH}$ & $80.2 \mathrm{CH}$ \\
\hline 4 & $40.6 \mathrm{qC}$ & $40.8 \mathrm{qC}$ & $41.9 \mathrm{qC}$ & $40.5 \mathrm{qC}$ & $40.6 \mathrm{qC}$ \\
\hline 5 & $42.0 \mathrm{CH}$ & $42.4 \mathrm{CH}$ & $46.4 \mathrm{CH}$ & $39.4 \mathrm{CH}$ & $39.4 \mathrm{CH}$ \\
\hline 6 & $33.5 \mathrm{CH}_{2}$ & $33.4 \mathrm{CH}_{2}$ & $34.1 \mathrm{CH}_{2}$ & $34.3 \mathrm{CH}_{2}$ & $34.3 \mathrm{CH}_{2}$ \\
\hline 7 & $172.7 \mathrm{qC}$ & $173.6 \mathrm{qC}$ & $173.4 \mathrm{qC}$ & $172.9 \mathrm{qC}$ & $172.9 \mathrm{qC}$ \\
\hline 8 & $73.5 \mathrm{qC}$ & $73.6 \mathrm{qC}$ & $124.6 \mathrm{qC}$ & $132.2 \mathrm{qC}$ & $132.3 \mathrm{qC}$ \\
\hline 9 & $51.3 \mathrm{qC}$ & $51.2 \mathrm{qC}$ & $161.9 \mathrm{qC}$ & $46.8 \mathrm{CH}$ & $46.7 \mathrm{CH}$ \\
\hline 10 & $53.1 \mathrm{qC}$ & $53.5 \mathrm{qC}$ & $60.5 \mathrm{qC}$ & $56.4 \mathrm{qC}$ & $56.4 \mathrm{qC}$ \\
\hline 11 & $16.7 \mathrm{CH}_{2}$ & $16.5 \mathrm{CH}_{2}$ & $20.6 \mathrm{CH}_{2}$ & $18.5 \mathrm{CH}_{2}$ & $18.6 \mathrm{CH}_{2}$ \\
\hline 12 & $30.1 \mathrm{CH}_{2}$ & $30.3 \mathrm{CH}_{2}$ & $30.7 \mathrm{CH}_{2}$ & $31.3 \mathrm{CH}_{2}$ & $31.3 \mathrm{CH}_{2}$ \\
\hline 13 & $38.1 \mathrm{qC}$ & $37.9 \mathrm{qC}$ & $37.8 \mathrm{qC}$ & $41.1 \mathrm{qC}$ & $41.1 \mathrm{qC}$ \\
\hline 14 & $65.4 \mathrm{qC}$ & $65.1 \mathrm{qC}$ & $151.7 \mathrm{qC}$ & $139.4 \mathrm{gC}$ & $139.3 \mathrm{qC}$ \\
\hline 15 & $35.2 \mathrm{CH}_{2}$ & $35.5 \mathrm{CH}_{2}$ & $113.8 \mathrm{CH}$ & $32.8 \mathrm{CH}_{2}$ & $32.9 \mathrm{CH}_{2}$ \\
\hline
\end{tabular}


Table 2. Cont.

\begin{tabular}{|c|c|c|c|c|c|}
\hline Position & $1^{a}$ & $1^{b}$ & $2^{a}$ & $3^{a}$ & $4^{a}$ \\
\hline 16 & $169.1 \mathrm{qC}$ & $169.0 \mathrm{qC}$ & $165.4 \mathrm{qC}$ & $169.5 \mathrm{qC}$ & $169.5 \mathrm{qC}$ \\
\hline 17 & $76.9 \mathrm{CH}$ & $76.9 \mathrm{CH}$ & $80.2 \mathrm{CH}$ & $80.3 \mathrm{CH}$ & $80.3 \mathrm{CH}$ \\
\hline 18 & $16.2 \mathrm{CH}_{3}$ & $16.6 \mathrm{CH}_{3}$ & $16.3 \mathrm{CH}_{3}$ & $16.6 \mathrm{CH}_{3}$ & $16.7 \mathrm{CH}_{3}$ \\
\hline 19 & $16.2 \mathrm{CH}_{3}$ & $16.0 \mathrm{CH}_{3}$ & $13.7 \mathrm{CH}_{3}$ & $15.6 \mathrm{CH}_{3}$ & $15.6 \mathrm{CH}_{3}$ \\
\hline 20 & $119.8 \mathrm{qC}$ & $120.3 \mathrm{qC}$ & $120.3 \mathrm{qC}$ & $120.4 \mathrm{qC}$ & $120.4 \mathrm{qC}$ \\
\hline 21 & $141.7 \mathrm{CH}$ & $141.7 \mathrm{CH}$ & $141.2 \mathrm{CH}$ & $141.3 \mathrm{CH}$ & $141.3 \mathrm{CH}$ \\
\hline 22 & $109.5 \mathrm{CH}$ & $110.0 \mathrm{CH}$ & $110.1 \mathrm{CH}$ & $110.0 \mathrm{CH}$ & $110.0 \mathrm{CH}$ \\
\hline 23 & $143.4 \mathrm{CH}$ & $144.6 \mathrm{CH}$ & $143.0 \mathrm{CH}$ & $143.1 \mathrm{CH}$ & $143.0 \mathrm{CH}$ \\
\hline 28 & $19.1 \mathrm{CH}_{3}$ & $18.8 \mathrm{CH}_{3}$ & $21.2 \mathrm{CH}_{3}$ & $19.9 \mathrm{CH}_{3}$ & $19.9 \mathrm{CH}_{3}$ \\
\hline 29 & $42.9 \mathrm{CH}_{2}$ & $43.3 \mathrm{CH}_{2}$ & $41.2 \mathrm{CH}_{2}$ & $42.9 \mathrm{CH}_{2}$ & $42.9 \mathrm{CH}_{2}$ \\
\hline 30 & $86.3 \mathrm{qC}$ & $87.2 \mathrm{qC}$ & $92.6 \mathrm{qC}$ & $91.4 \mathrm{qC}$ & $91.4 \mathrm{qC}$ \\
\hline 7-OMe-31 & $51.9 \mathrm{CH}_{3}$ & $52.1 \mathrm{CH}_{3}$ & $52.0 \mathrm{CH}_{3}$ & $51.7 \mathrm{CH}_{3}$ & $51.8 \mathrm{CH}_{3}$ \\
\hline \multicolumn{6}{|l|}{ 3-OAcyl } \\
\hline 32 & $175.3 \mathrm{qC}$ & $175.2 \mathrm{qC}$ & $175.7 \mathrm{qC}$ & $175.6 \mathrm{qC}$ & $176.0 \mathrm{qC}$ \\
\hline 33 & $40.9 \mathrm{CH}$ & $40.8 \mathrm{CH}$ & $40.5 \mathrm{CH}$ & $40.7 \mathrm{CH}$ & $33.9 \mathrm{CH}$ \\
\hline 34 & $26.8 \mathrm{CH}_{2}$ & $26.7 \mathrm{CH}_{2}$ & $26.6 \mathrm{CH}_{2}$ & $27.0 \mathrm{CH}_{2}$ & $18.5 \mathrm{CH}_{3}$ \\
\hline 35 & $11.3 \mathrm{CH}_{3}$ & $11.6 \mathrm{CH}_{3}$ & $11.6 \mathrm{CH}_{3}$ & $11.5 \mathrm{CH}_{3}$ & $18.9 \mathrm{CH}_{3}$ \\
\hline 36 & $16.1 \mathrm{CH}_{3}$ & $16.3 \mathrm{CH}_{3}$ & $16.5 \mathrm{CH}_{3}$ & $16.3 \mathrm{CH}_{3}$ & \\
\hline \multicolumn{6}{|l|}{ 30-OAcyl } \\
\hline 37 & $175.4 \mathrm{qC}$ & $175.6 \mathrm{qC}$ & $175.9 \mathrm{qC}$ & $177.3 \mathrm{qC}$ & $177.4 \mathrm{qC}$ \\
\hline 38 & $33.5 \mathrm{CH}$ & $33.2 \mathrm{CH}$ & $33.8 \mathrm{CH}$ & $33.6 \mathrm{CH}$ & $33.6 \mathrm{CH}$ \\
\hline 39 & $18.7 \mathrm{CH}_{3}$ & $19.0 \mathrm{CH}_{3}$ & $18.8 \mathrm{CH}_{3}$ & $19.1 \mathrm{CH}_{3}$ & $19.1 \mathrm{CH}_{3}$ \\
\hline 40 & $18.8 \mathrm{CH}_{3}$ & $18.7 \mathrm{CH}_{3}$ & $19.1 \mathrm{CH}_{3}$ & $18.9 \mathrm{CH}_{3}$ & $19.1 \mathrm{CH}_{3}$ \\
\hline
\end{tabular}

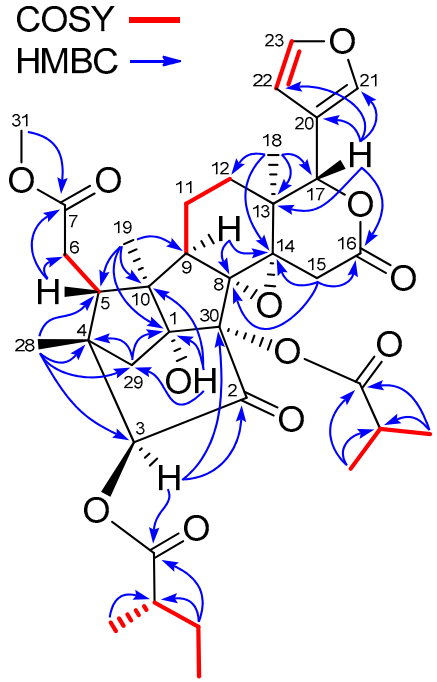

(a)

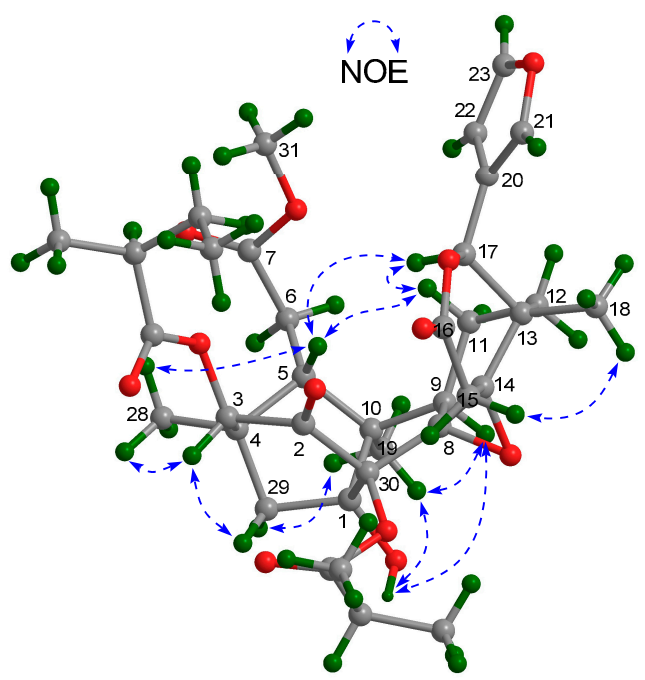

(b)

Figure 2. (a) Selected ${ }^{1} \mathrm{H}-{ }^{1} \mathrm{H}$ COSY and HMBC correlations for compound 1 (measured in DMSO- $d_{6}$ ); (b) Diagnostic Nuclear Overhauser Effect (NOE) interactions for compound 1 (measured in DMSO- $d_{6}$ ).

After considerable effort, suitable crystals of $\mathbf{1}$ were obtained in acetone/n-hexane (4:1) at room temperature. Thus, single-crystal $\mathrm{X}$-ray diffraction analysis, conducted with $\mathrm{CuK} \alpha$ radiation, was carried out to establish the relative and absolute configurations of $\mathbf{1}$. The absolute configuration of $\mathbf{1}$, named krishnolide A, was unequivocally established as $1 R, 3 S, 4 R, 5 S, 8 R, 9 R, 10 S, 13 S, 14 S, 17 S, 30 R, 33 S$ (Flack parameter of -0.06 (10), Flack $x$ of $-0.00(9)$, and Hooft y of $-0.00(4)$ ) [22]. Computer-generated perspective drawings of the X-ray structure of $\mathbf{1}$ are shown in Figure 3 and Figure S1. 


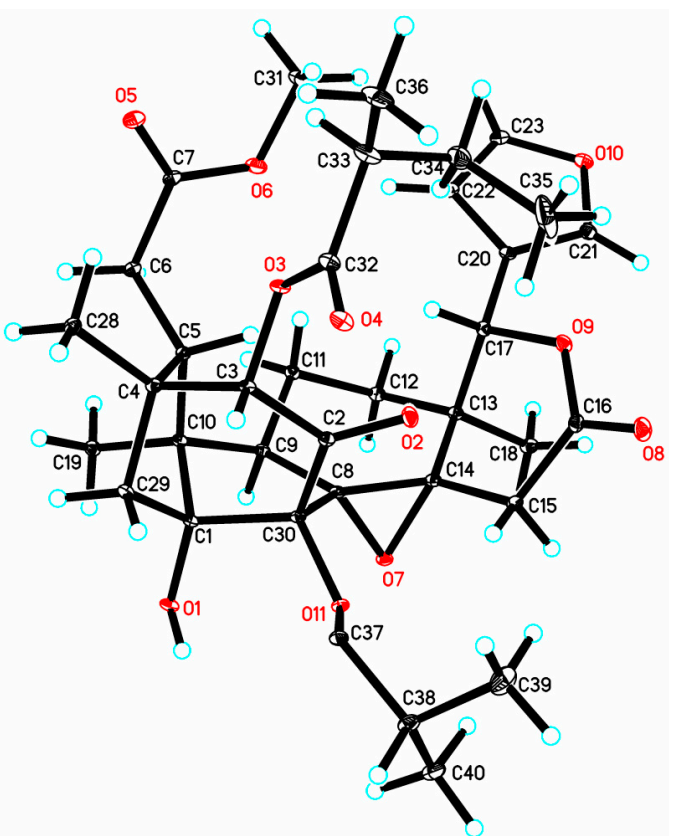

Figure 3. Oak Ridge Thermal-Ellipsoid Plot Program (ORTEP) illustration of the X-ray structure of compound 1. Ellipsoids are given at the $30 \%$ probability level.

Compound 2, a white amorphous powder, had the molecular formula $\mathrm{C}_{36} \mathrm{H}_{44} \mathrm{O}_{11}$ as established by the positive HR-ESIMS ion peak at $m / z 653.2956$ (calcd. for $[\mathrm{M}+\mathrm{H}]^{+} 653.2956$ ). The ${ }^{1} \mathrm{H}$ and ${ }^{13} \mathrm{C}$ NMR spectroscopic data of $\mathbf{2}$ (Tables 1 and 2) were similar to those of $\mathbf{1}$ except for the replacement of the 8,14-epoxy group in 1 by conjugated $\Delta^{8,9}$ and $\Delta^{14,15}$ double bonds $\left(\delta_{C} 124.6(\mathrm{C}-8, \mathrm{qC}), 161.9(\mathrm{C}-9, \mathrm{qC})\right.$, 151.7 (C-14, qC), 113.8 (C-15, CH)), which was corroborated by HMBC correlations between H-15/C-8, $\mathrm{H}-15 / \mathrm{C}-13, \mathrm{H}-15 / \mathrm{C}-14, \mathrm{H}-15 / \mathrm{C}-16, \mathrm{H}_{3}-18 / \mathrm{C}-14$, and $\mathrm{H}_{3}-19$ /C-9. The relative configuration of 2 was determined to be the same as that of 1 by NOE interactions between $\mathrm{H}-17 / \mathrm{H}-12 \beta, \mathrm{H}-5 / \mathrm{H}-11 \beta$, $\mathrm{H}-5 / \mathrm{H}_{3}-28, \mathrm{H}-19 / \mathrm{H}_{\text {pro-s }}-29$, and those between $\mathrm{H}_{3}-18 / \mathrm{H}-11 \alpha, \mathrm{H}-3 / \mathrm{H}_{\text {pro- } \mathrm{R}}-29$. The absolute configuration of 2 , named krishnolide $B$, was established to be the same as that of thaixylomolin $\mathrm{N}(1 R, 3 S, 4 R, 5 S, 10 S, 13 R, 17 R, 30 S$-configured) by the similarity of their electronic circular dichroism (ECD) spectra (Figure 4a) [6].

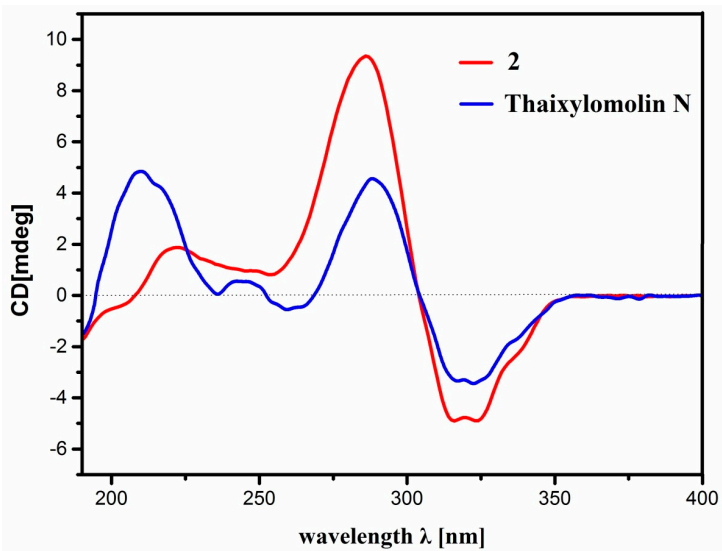

(a)

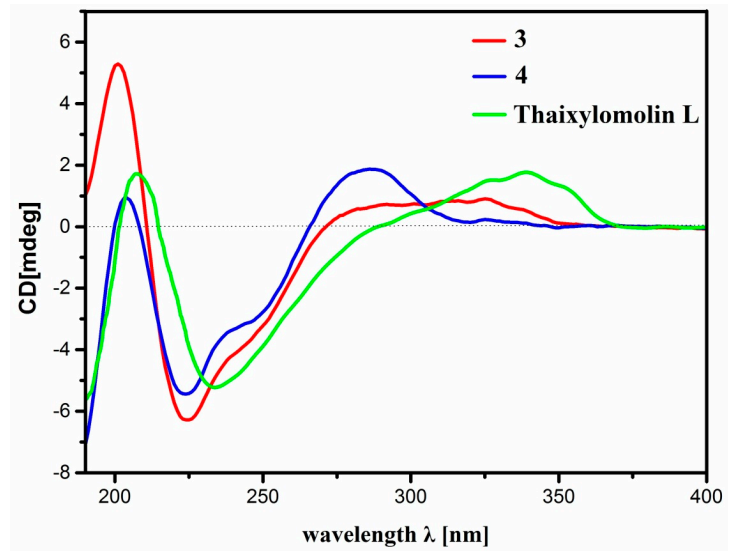

(b)

Figure 4. (a) Comparison of the experimental circular dichroism (CD) spectra of compound 2 and the known compound, thaixylomolin $\mathrm{N}$, containing conjugated $\Delta^{8,9}$ and $\Delta^{14,15}$ double bonds; (b) Comparison of the experimental CD spectra of compounds 3, 4, and the known compound, thaixylomolin L, containing a $\Delta^{8,9}$ double bond. 
Compound 3 provided the molecular formula $\mathrm{C}_{36} \mathrm{H}_{46} \mathrm{O}_{11}$, as established by the positive HR-ESIMS ion peak at $m / z 677.2917$ (calcd. for $[\mathrm{M}+\mathrm{Na}]^{+}$677.2932). The NMR spectroscopic data of 3 (Tables 1 and 2) displayed structural similarity to that of $\mathbf{1}$, except for the replacement of the 8,14-epoxy group in 1 by a $\Delta^{8,14}$ double bond $\left(\delta_{\mathrm{C}} 132.2(\mathrm{C}-8, \mathrm{qC}), 139.4(\mathrm{C}-14, \mathrm{qC})\right)$ in $3 .{ }^{1} \mathrm{H}-{ }^{1} \mathrm{H}$ COSY homoallylic couplings between $\mathrm{H}_{2}-15 / \mathrm{H}-9$ and $\mathrm{HMBC}$ correlations between $\mathrm{H}_{2}-15 / \mathrm{C}-8, \mathrm{H}_{2}-15 / \mathrm{C}-14, \mathrm{H}_{3}-18 / \mathrm{C}-14$, $\mathrm{H}-17 / \mathrm{C}-14$, and $\mathrm{H}-9 / \mathrm{C}-8$ confirmed the existence of the $\Delta^{8,14}$ double bond. The relative configuration of 3 was deduced to be identical to that of 1 by NOE interactions between $\mathrm{H}-17 / \mathrm{H}-12 \beta, \mathrm{H}-11 \beta / \mathrm{H}-5$, $\mathrm{H}-17 / \mathrm{H}-5, \mathrm{H}-5 / \mathrm{H}_{3}-28$, and those between $\mathrm{H}_{3}-18 / \mathrm{H}-15 \alpha, \mathrm{H}_{3}-18 / \mathrm{H}-9, \mathrm{H}_{3}-19 / \mathrm{H}-9, \mathrm{H}-3 / \mathrm{H}_{\text {pro-R }}-29$. The absolute configuration of 3 , named krishnolide $C$, was established to be the same as that of thaixylomolin $\mathrm{L}(1 R, 3 S, 4 R, 5 S, 9 R, 10 S, 13 R, 17 R, 30 S$-configured) by the similarity of their ECD spectra (Figure 4b) [6].

The molecular formula of 4 was assigned as $\mathrm{C}_{35} \mathrm{H}_{44} \mathrm{O}_{11}$ by the positive HR-ESIMS ion peak at $m / z 663.2771$ (calcd. for $[\mathrm{M}+\mathrm{Na}]^{+}$663.2776). The NMR spectroscopic data of 4 (Tables 1 and 2) were similar to those of 3 , except for the replacement of the 3-(2-methyl)butyryloxy group in 3 by an isobutyryloxy moiety $\left(\delta_{\mathrm{H}} 2.65(1 \mathrm{H}, \mathrm{m}, \mathrm{H}-33), 1.19\left(3 \mathrm{H}, \mathrm{d}, J=7.2 \mathrm{~Hz}, \mathrm{H}_{3}-34\right), 1.20(3 \mathrm{H}, \mathrm{d}, J=7.2 \mathrm{~Hz}\right.$, $\left.\left.\mathrm{H}_{3}-35\right) ; \delta_{\mathrm{C}} 176.0(\mathrm{C}-32, \mathrm{qC}), 33.8(\mathrm{C}-33, \mathrm{CH}), 18.5\left(\mathrm{C}-34, \mathrm{CH}_{3}\right), 18.9\left(\mathrm{C}-35, \mathrm{CH}_{3}\right)\right)$ in 4 . The existence of the isobutyryloxy group was corroborated by ${ }^{1} \mathrm{H}^{-1} \mathrm{H}$ COSY cross-peaks between $\mathrm{H}-33 / \mathrm{H}_{3}-34$ and $\mathrm{H}-33 / \mathrm{H}_{3}-35$, and $\mathrm{HMBC}$ correlations between $\mathrm{H}-33 / \mathrm{C}-32, \mathrm{H}_{3}-34 / \mathrm{C}-32$, and $\mathrm{H}_{3}-35 / \mathrm{C}-32$. The strong HMBC correlation from $\mathrm{H}-3(\delta 5.21, \mathrm{~s})$ to the carbonyl carbon $(\delta 176.0(\mathrm{C}-32))$ of the isobutyryloxy group confirmed its location at $\mathrm{C}-3$. The relative configuration of 4 was determined to be the same as that of 3 based on NOE interactions between $\mathrm{H}-17 / \mathrm{H}-12 \beta, \mathrm{H}-11 \beta / \mathrm{H}-5, \mathrm{H}-5 / \mathrm{H}_{3}-28$, and those between $\mathrm{H}_{3}-18 / \mathrm{H}-15 \alpha, \mathrm{H}_{3}-18 / \mathrm{H}-9, \mathrm{H}_{3}-19 / \mathrm{H}-9, \mathrm{H}-3 / \mathrm{H}_{\text {pro- }}-29$. The absolute configuration of 4 , named krishnolide $\mathrm{D}$, was established to be the same as that of $\mathbf{3}(1 R, 3 S, 4 R, 5 S, 9 R, 10 S, 13 R, 17 R, 30 S$-configured) by the similarity of their ECD spectra (Figure $4 b$ ) [6].

Anti-HIV activities of 1-4 were tested in vitro by HIV-I virus-transfected $293 \mathrm{~T}$ cells [23]. At the concentration of $20 \mu \mathrm{M}$, only 1 showed a strong inhibitory rate of $79.75 \pm 0.77 \%$. Efavirenz was used as the positive control, with an inhibitory rate of $88.54 \pm 0.45 \%$ at the same concentration. Values of $\mathrm{IC}_{50}$ and $\mathrm{CC}_{50}$ for $\mathbf{1}$ were $17.45 \pm 1.65$ and $78.45 \pm 1.69 \mu \mathrm{M}$, respectively. Structure-activity relationship analyses of 1-4 concluded that the 8,14-epoxy group is pivotal for the anti-HIV activity of khayanolides. However, only two other khayanolides with an 8,14-epoxy group, viz. khayanolide A and 1-O-acetylkhayanolide A, have hitherto been reported [9,12].

Previously, 36 khayanolides were reported. These khayanolides exhibited antifeedant, antiacetylcholinesterase, anti-butyrycholinesterase, anti-lipoxygenase, antitumor, antimicrobial, and anti-H1N1 (antiviral) activities [8-21], but no khayanolide has previously been reported to have anti-HIV activity. In this paper, the anti-HIV activities of khayanolides were reported for the first time.

\section{Materials and Methods}

\subsection{General Methods}

Optical rotations were determined with an MCP 200 modular circular polarimeter (Anton Paar Opto Tec GmbH, Seelze, Germany). UV spectra were recorded on a GENESYS 10S UV-Vis spectrophotometer (Thermo Fisher Scientific, Shanghai, China), and HR-ESIMS was obtained on an LC-ESIMS system in the positive-ion mode (Bruker Daltonics, Bremen, Germany). NMR spectra were measured on a Bruker AV-400 NMR spectrometer. Preparative HPLC was carried out on C18 reversed-phase columns (YMC, $250 \times 10 \mathrm{~mm}$ i.d., $5 \mu \mathrm{m}$ ) using a Waters 2535 pump equipped with a Waters 2489 UV detector (Waters Corporation, Milford, MA, USA). Single-crystal X-ray diffraction analysis of $\mathbf{1}$ was performed on an Agilent Xcalibur Atlas Gemini Ultra-diffractometer with mirror monochromated CuK $\alpha$ radiation $(\lambda=1.54184 \AA)$ at $150 \mathrm{~K}$. Silica gel (100-200 mesh) (Qingdao Mar. Chem. Ind. Co. Ltd., Qingdao, China) and C18 reversed-phase silica gel (50 $\mu \mathrm{m}$, YMC Co. Ltd., Kyoto, Japan) were used for column chromatography. 


\subsection{Plant Material}

Seeds of Xylocarpus moluccensis were collected in September 2007 at the mangrove swamp of Krishna estuary, Andhra Pradesh, India. Identification of the mangrove was done by one of the authors (T.S.). A voucher sample (No. IXM200701) is maintained in Marine Drugs Research Center, College of Pharmacy, Jinan University.

\subsection{Extraction and Isolation}

The air-dried seeds $(6.0 \mathrm{~kg})$ of $X$. moluccensis were powdered and extracted with $95 \% \mathrm{EtOH}$ $(6 \times 15 \mathrm{~L})$ at room temperature to afford the resulting extract $(824.6 \mathrm{~g})$, which was suspended in water $(2.5 \mathrm{~L})$ and extracted with EtOAc $(6 \times 7.5 \mathrm{~L})$ to afford the EtOAc portion $(299.1 \mathrm{~g})$. The EtOAc portion was chromatographed on a silica gel column $(150 \times 8.5 \mathrm{~cm}$ i.d.), eluted with a gradient mixture of $\mathrm{CHCl}_{3} / \mathrm{MeOH}(100: 0$ to $5: 1, v / v)$ to afford 223 fractions. Fractions 68-71 (22.9 g) were combined and further purified by $\mathrm{C} 18$ reversed-phase silica gel column chromatography $(60 \times 3 \mathrm{~cm}$ i.d. $)$, and eluted with a gradient mixture of acetone $/ \mathrm{H}_{2} \mathrm{O}(40: 60$ to 100:0, $v / v)$ to yield 111 subfractions, among which subfractions 63-65 (351.2 mg) were combined and purified by preparative HPLC (MeCN/ $\left.\mathrm{H}_{2} \mathrm{O}, 55: 45\right)$ to give compounds $1\left(t_{R}=51.5 \mathrm{~min}, 20.2 \mathrm{mg}\right)$ and $\mathbf{2}\left(\mathrm{t}_{R}=46.6 \mathrm{~min}, 4.4 \mathrm{mg}\right)$. Fractions 58-67 (43.0 g) were combined and separated by C18 reversed-phase silica gel column chromatography ( $58 \times 5.5 \mathrm{~cm}$ i.d.), and eluted with a gradient mixture of acetone $/ \mathrm{H}_{2} \mathrm{O}(40: 60$ to 100:0, $v / v)$ to give 136 subfractions, among which the subfraction $98(1.5 \mathrm{~g})$ was subjected to preparative $\mathrm{HPLC}\left(\mathrm{MeCN} / \mathrm{H}_{2} \mathrm{O}, 55: 45\right)$ to yield compound $3\left(t_{R}=45.5 \mathrm{~min}, 7.1 \mathrm{mg}\right)$, whereas the subfraction $100(820.2 \mathrm{mg})$ was purified by preparative HPLC $\left(\mathrm{MeOH} / \mathrm{H}_{2} \mathrm{O}, 65: 35\right)$ to give compound $4\left(\mathrm{t}_{\mathrm{R}}=48.3 \mathrm{~min}, 2.5 \mathrm{mg}\right)$.

Krishnolide A (1). Colorless crystal, $[a]_{\mathrm{D}}^{25}=-48\left(c\right.$ 0.1, acetone); UV (MeCN) $\lambda_{\max }(\log \varepsilon) 208(3.80)$ $\mathrm{nm}$; ECD (c $1.49 \mathrm{mM}, \mathrm{MeCN}) \lambda_{\max }(\Delta \varepsilon) 195(-0.4), 208(-0.5), 229(-0.8), 326(+0.5) \mathrm{nm} ;$ HR-ESIMS $m / z$ 693.2871 [M + Na] ${ }^{+}$(calcd. for $\mathrm{C}_{36} \mathrm{H}_{46} \mathrm{NaO}_{12}, 693.2887$ ); ${ }^{1} \mathrm{H}$ and ${ }^{13} \mathrm{C}$ NMR spectroscopic data see Tables 1 and 2.

Krishnolide B (2). White, amorphous solid, $[a]_{\mathrm{D}}^{25}=+36$ (c 0.1, acetone); UV (MeCN) $\lambda_{\max }(\log \varepsilon)$ 207 (3.81), 282 (3.99) nm; ECD (c $0.19 \mathrm{mM}, \mathrm{MeCN}) \lambda_{\max }(\Delta \varepsilon) 222(+3.0), 286(+14.8), 324(-7.7) \mathrm{nm}$; HR-ESIMS $m / z 653.2956[\mathrm{M}+\mathrm{H}]^{+}$(calcd. for $\left.\mathrm{C}_{36} \mathrm{H}_{45} \mathrm{O}_{11}, 653.2962\right) ;{ }^{1} \mathrm{H}$ and ${ }^{13} \mathrm{C}$ NMR spectroscopic data see Tables 1 and 2.

Krishnolide C (3). White, amorphous solid, $[a]_{\mathrm{D}}^{25}=-38$ ( 0.1 , acetone); UV (MeCN) $\lambda_{\max }(\log \varepsilon)$ 206 (3.84) nm; ECD (c $0.38 \mathrm{mM}, \mathrm{MeCN}) \lambda_{\max }(\Delta \varepsilon) 201(+4.2), 225(-5.0), 325(+0.7) \mathrm{nm} ;$ HR-ESIMS $m / z$ 677.2917 [M + Na] ${ }^{+}$(calcd. for $\left.\mathrm{C}_{36} \mathrm{H}_{46} \mathrm{NaO}_{11}, 677.2932\right) ;{ }^{1} \mathrm{H}$ and ${ }^{13} \mathrm{C}$ NMR spectroscopic data see Tables 1 and 2.

Krishnolide D (4). White, amorphous solid, $[a]_{\mathrm{D}}^{25}=-54$ (c 0.1, acetone); UV (MeCN) $\lambda_{\max }(\log \varepsilon)$ 204 (4.35) nm; ECD (c $0.39 \mathrm{mM}, \mathrm{MeCN}) \lambda_{\max }(\Delta \varepsilon) 204$ (+0.7), 224 (-4.2), $286(+1.5) \mathrm{nm}$; HR-ESIMS $m / z 663.2771[\mathrm{M}+\mathrm{Na}]^{+}$(calcd. for $\left.\mathrm{C}_{35} \mathrm{H}_{44} \mathrm{NaO}_{11}, 663.2776\right) ;{ }^{1} \mathrm{H}$ and ${ }^{13} \mathrm{C}$ NMR spectroscopic data see Tables 1 and 2.

\subsection{X-ray Crystal Data for Krishnolide A (1)}

Monoclinic, $\mathrm{C}_{36} \mathrm{H}_{46} \mathrm{O}_{12}$, space group P2(1), $\mathrm{a}=9.33350$ (10) $\AA, \mathrm{b}=18.00600$ (10) $\AA$, $c=10.73330(10) \AA, \alpha=90^{\circ}, \beta=113.9990(10)^{\circ}, \gamma=90^{\circ}, V=1647.89(3) \AA^{3}, Z=2, D_{\text {calcd. }}=1.352 \mathrm{Mg} / \mathrm{m}^{3}$, $\mu=0.839 \mathrm{~mm}^{-1}$. Crystal size: $0.40 \times 0.34 \times 0.30 \mathrm{~mm}^{3} .5929$ measured reflections, $5810\left(R_{\text {int }}=0.0350\right)$ independent reflections, 442 parameters, one restraints, $F(000)=716, R_{1}=0.0312, w R_{2}=0.0800$ (all data), $R_{1}=0.0304, w R_{2}=0.0789(I>2 \sigma(I))$, and goodness-of-fit $\left(F^{2}\right)=1.048$. The absolute structural parameter is $-0.06(10)$, the Flack $x$ parameter is $-0.00(9)$, and the value of Hooft $y$ is $-0.00(4)$.

CCDC-1573579 (1) contains the supplementary crystallographic data for this paper (excluding structure factors). These data are provided free of charge by The Cambridge Crystallographic Data Centre. 


\subsection{HIV-Inhibitory Bioassay}

A total of $293 \mathrm{~T}$ cells $\left(2 \times 10^{5}\right)$ were co-transfected with $0.6 \mu \mathrm{g}$ of $\mathrm{pNL}-\mathrm{Luv}_{-} \mathrm{E}^{-}-\mathrm{Vpu}^{-}$and $0.4 \mu \mathrm{g}$ of pHIT/G. After $48 \mathrm{~h}$, the VSV-G pseudotyped viral supernatant (HIV-1) was harvested by filtration through a $0.45-\mu \mathrm{m}$ filter and the concentration of viral capsid protein was determined by p24 antigen capture ELISA (Biomerieux). SupT1 cells were exposed to VSV-G pseudotyped HIV-1 (MOI = 1) at $37^{\circ} \mathrm{C}$ for $48 \mathrm{~h}$ in the absence or presence of the test compounds 1-4 (Efavirenz was used as the positive control). The inhibition rates were determined by using a firefly Luciferase Assay System (Promega) [23].

\section{Conclusions}

In conclusion, four new khayanolides, containing a 2-methylbutyryloxy or an isobutyroxy substituent at the C-3 and C-30 positions, respectively, were first obtained from the seeds of an Indian mangrove, Xylocarpus moluccensis. The relative and absolute configurations of these compounds were established by HR-ESIMS, extensive NMR investigations, single-crystal X-ray diffraction analysis with $\mathrm{CuK} \alpha$ radiation, and experimental electronic circular dichroism (ECD) spectra. Krishnolide A exhibited moderate anti-HIV activity. The 8,14-epoxy group is pivotal for its anti-HIV activity. This is the first anti-HIV report of khayanolides.

Supplementary Materials: The following are available online at www.mdpi.com/1660-3397/15/11/333/s1. Copies of HR-ESIMS, and 1D, 2D NMR spectra of Krishnolides A-D (1-4).

Acknowledgments: This work was financially supported by NSFC (U1501221, 31770377, 81661148049, and 81125022), the Pearl River S \& T Nova Program of Guangzhou, China (201506010023), the Science and Technology Planning Project of Guangdong Province, China (2013B051000057), and the Fundamental Research Funds for the Central Universities, China (21617474).

Author Contributions: Li Shen and Jun Wu conceived and designed the experiments; Qun Zhang performed the experiments, analyzed the data and wrote the draft; Tirumani Satyanandamurty contributed plant materials; $\mathrm{Li}$ Shen and Jun $\mathrm{Wu}$ revised the paper. All authors have read and approved the manuscript.

Conflicts of Interest: The authors declare no conflict of interest.

\section{References}

1. Tan, Q.G.; Luo, X.D. Meliaceous limonoids: Chemistry and biological activities. Chem. Rev. 2011, 111, 7437-7522. [CrossRef] [PubMed]

2. Wu, J.; Xiao, Q.; Xu, J.; Li, M.Y.; Pan, J.Y.; Yang, M.H. Natural Products from True Mangrove Flora: Source, Chemistry and Bioactivities. Nat. Prod. Rep. 2008, 25, 955-981. [CrossRef] [PubMed]

3. Ye, F.; Li, X.W.; Guo, Y.W. Recent Progress on the Mangrove Plants: Chemistry and Bioactivity. Curr. Org. Chem. 2016, 20, 1923-1942. [CrossRef]

4. Li, W.S.; Wu, J.; Li, J.; Satyanandamurty, T.; Shen, L.; Bringmann, G. Krishnadimer A, an axially chiral non-biaryl natural product: Discovery and biomimetic synthesis. Org. Lett. 2017, 19, 182-185. [CrossRef] [PubMed]

5. Dai, Y.G.; Li, W.S.; Pedpradab, P.; Liu, J.J.; Wu, J.; Shen, L. Thaixylomolins O-R: Four new limonoids from the Trang mangrove, Xylocarpus moluccensis. RSC Adv. 2016, 6, 85978-85984. [CrossRef]

6. Li, W.S.; Jiang, Z.P.; Shen, L.; Pedpradab, P.; Bruhn, T.; Wu, J.; Bringmann, G. Antiviral limonoids including khayanolides from the Trang mangrove plant Xylocarpus moluccensis. J. Nat. Prod. 2015, 78, 1570-1578. [CrossRef] [PubMed]

7. Li, J.; Li, M.Y.; Bruhn, T.; Katele, F.Z.; Xiao, Q.; Pedpradab, P.; Wu, J.; Bringmann, G. Thaixylomolins A-C: Limonoids featuring two new motifs from the Thai Xylocarpus moluccensis. Org. Lett. 2013, 15, 3682-3685. [CrossRef] [PubMed]

8. Olmo, L.R.V.; Silva, M.F.; Das, G.F.D.; Fo, E.R.; Vieira, P.C.; Fernandes, J.B.; Marsaioli, A.J.; Pinheiro, A.L.; Vilela, E.F. Rearranged limonoids from Khaya senegalensis. Phytochemistry 1996, 42, 831-837. [CrossRef] 
9. Nakatani, M.; Abdelgaleil, S.A.M.; Okamura, H.; Iwagawa, T.; Sato, A.; Doe, M. Khayanolides A and B, new rearranged phragmalin limonoid antifeedants from Khaya senegalensis. Tetrahedron Lett. 2000, 41, 6473-6477. [CrossRef]

10. Abdelgaleil, S.A.M.; Okamura, H.; Iwagawa, T.; Sato, A.; Miyahara, I.; Doe, M.; Nakatani, M. Khayanolides, rearranged phragmalin limonoid antifeedants from Khaya senegalensis. Tetrahedron 2001, 57, 119-126. [CrossRef]

11. Nakatani, M.; Abdelgaleil, S.A.M.; Kassem, S.M.I.; Takezaki, K.; Okamura, H.; Iwagawa, T.; Doe, M.J. Three new modified limonoids from Khaya senegalensis. J. Nat. Prod. 2002, 65, 1219-1221. [CrossRef] [PubMed]

12. Abdelgaleil, S.A.M.; Nakatani, M.J. Antifeeding activity of limonoids from Khaya senegalensis. Appl. Entomol. 2003, 127, 236-239. [CrossRef]

13. El-Aswad, A.F.; Abdelgaleil, S.A.M.; Nakatani, M. Feeding deterrent and growth inhibitory properties of limonoids from Khaya senegalensis against the cotton leafworm, Spodoptera littoralis. Pest Manag. Sci. 2003, 60, 199-203. [CrossRef] [PubMed]

14. Zhang, H.; Odeku, O.A.; Wang, X.N.; Yue, J.M. Limonoids from the stem bark of Khaya grandifoliola. Phytochemistry 2008, 69, 271-275. [CrossRef] [PubMed]

15. Zhang, H.P.; Tan, J.J.; VanDerveer, D.; Wang, X.; Wargovich, M.J.; Chen, F. Khayanolides from African mahogany Khaya senegalensis (Meliaceae): A revision. Phytochemistry 2009, 70, 294-299. [CrossRef] [PubMed]

16. Zhang, B.; Yang, S.P.; Yin, S.; Zhang, C.R.; Wu, Y.; Yue, J.M. Phytochemistry Limonoids from Khaya ivorensis. Phytochemistry 2009, 70, 1305-1308. [CrossRef] [PubMed]

17. Jabeen, B.; Riaz, N.; Saleem, M.A.; Naveed, M.A.; Ahmed, M.; Tahir, M.N.; Pescitelli, G.; Ashraf, M.; Ejaz, S.A.; Ahmed, I.; et al. Isolation and characterization of limonoids from Kigelia africana. Z. Naturforsch. 2013, 68b, 1041-1048. [CrossRef]

18. Yuan, C.M.; Zhang, Y.; Tang, G.H.; Hao, X.J. Khayseneganins A-H, limonoids from Khaya senegalensis. J. Nat. Prod. 2013, 76, 327-333. [CrossRef] [PubMed]

19. Zhang, W.M.; Xia, J.J.; Qiu, M.H.; Li, Z.R. Diterpenoids and limonoids from the leaves and twigs of Swietenia mahagoni. Nat. Prod. Bioprospect. 2014, 4, 53-57. [CrossRef] [PubMed]

20. Wu, Y.B.; Qing, X.; Huo, C.H.; Yan, H.M.; Shi, Q.W.; Sauriol, F.; Gu, Y.C.; Kiyota, H. Ivorenoids A-F: Limonoids from Khaya ivorensis. Tetrahedron 2014, 70, 3570-3575. [CrossRef]

21. Li, Y.; Lu, Q.P.; Luo, J.; Wang, J.S.; Wang, X.B.; Zhu, M.D.; Kong, L.Y. Limonoids from the stem bark of Khaya senegalensis. Chem. Pharm. Bull. 2015, 63, 305-310. [CrossRef] [PubMed]

22. Hooft, R.W.W.; Straver, L.H.; Spek, A.L. Determination of absolute structure using Bayesian statistics on Bijvoet differences. J. Appl. Cryst. 2008, 41, 96-103. [CrossRef] [PubMed]

23. Zhang, Q.; Liu, Z.L.; Mi, Z.Y.; Li, X.Y.; Jia, P.P.; Zhou, J.M.; Yin, X.; You, X.F.; Yu, L.Y.; Guo, F.; et al. High-throughput assay to identify inhibitors of Vpu-mediated down-regulationof cell surface BST-2. Antivir. Res. 2011, 91, 321-329. [CrossRef] [PubMed]

(C) 2017 by the authors. Licensee MDPI, Basel, Switzerland. This article is an open access article distributed under the terms and conditions of the Creative Commons Attribution (CC BY) license (http:// creativecommons.org/licenses/by/4.0/). 